\title{
Ability of corneal biomechanical metrics and anterior segment data in the differentiation of keratoconus and healthy corneas
}

\author{
Estudo da performance diagnóstica de parâmetros biomecânicos e dados anatômicos \\ da câmara anterior na diferenciação de córneas saudáveis e com ceratocone
}

Bruno Machado Fontes ${ }^{1}$, Renato Ambrósio Junior ${ }^{2}$,Daniela Jardim ${ }^{3}$, Guillermo Coca Velarde ${ }^{4}$, Walton Nosé 1,5

\begin{abstract}
Purpose: To evaluate the sensitivity, specificity, and test accuracy of corneal biomechanical metrics and anterior segment data in differentiating keratoconus from healthy corneas.

Methods: Comparative case series. Patients with and without keratoconus (gender and age-matched) were submitted for complete eye examinations including corneal hysteresis $(\mathrm{CH})$ and corneal resistance factor (CRF) as measured by the Ocular Response Analyzer and anterior segment data as gathered through Pentacam assessments. The anterior segment data measurement included average central keratometric readings (K-Ave), corneal astigmatism (CA), central corneal thickness (CCT), anterior chamber depth (AC depth) and corneal volume (CV). All parameters were assessed, compared and analyzed. A receiver operating characteristic (ROC) curve was used to identify the best cutoff point by which to maximize the sensitivity and specificity of discriminating keratoconus from normal corneas for each data category.

Results: Seventy seven eyes from forty three patients (24 male, 19 female) with keratoconus and eighty six eyes from forty three (24 male, 19 female) healthy controls were enrolled. ROC curve analysis showed poor overall predictive accuracy for all studied parameters in differentiating keratoconus from normal corneas. The highest sensitivity (79.2\%) was obtained for both AC depth and $\mathrm{CH}$ (cutoff points $3.22 \mathrm{~mm}$ and $9.39 \mathrm{mmHg}$ respectively). The best specificity (89.5\%) and test accuracy (80.34\%) were obtained for CA (cutoff point of 2.2 D).

Conclusion: When considered together, studied parameters showed statistical differences between groups. However, when considered independently they presented low sensitivity, specificity and test accuracy in differentiating keratoconus from healthy corneas.
\end{abstract}

Keywords: Cornea; Corneal diseases; Corneal topography; Biomechanics; Keratoconus.

\section{RESUMO}

Objetivo: Avaliar a sensibilidade, especificidade e acurácia de parâmetros biomecânicos e anatômicos do segmento anterior isolados na diferenciação de córneas saudáveis e com ceratocone.

Métodos: Estudo tipo série de casos comparativa. Pacientes com ceratocone e controles saudáveis foram pareados (idade e sexo) e submetidos a exame oftalmológico completo, incluindo avaliação biomecânica (ORA) e tomográfica (Pentacam). Ceratometria central média, astigmatismo corneano, espessura corneana central, profundidade da câmara anterior, volume corneano, CH e CRF foram estabelecidos, avaliados e comparados. Curvas ROC (Receiver operating characteristic) foram utilizadas para identificar o melhor valor de corte que apresentasse a maior sensibilidade e especificidade na discriminação entre ceratocone e córneas saudáveis para cada dado estudado.

Resultados: Setenta e sete olhos de 43 pacientes com ceratocone (24 homens e 19 mulheres) e 86 olhos de pacientes saudáveis (24 homens e 19 mulheres) foram incluídos no estudo. Curvas ROC mostraram baixa acurácia na predição do diagnóstico de ceratocone em todos os parâmetros isolados estudados. Maior sensibilidade encontrada foi $79,2 \%$ para profundidade da câmara anterior e $\mathrm{CH}$ (ponto de corte $3,22 \mathrm{~mm}$ e $9,39 \mathrm{mmHg}$ respectivamente); maior especificidade e acurácia foram encontradas na análise do astigmatismo corneano (ponto de corte 2,2 D; 89,5\% e 80,34\% respectivamente).

Conclusão: Todos os parâmetros estudados mostraram diferença estatisticamente significativa entre os grupos. No entanto, quando considerados isoladamente apresentaram baixas sensibilidade, especificidade e acurácia na diferenciação entre ceratocone e córneas saudáveis.

Descritores: Córnea; Doenças da córnea; Topografia da córnea; Biomecânica; Ceratocone
Study carried out at Ophthalmology Department, Escola Paulista de Medicina, Universidade Federal de São Paulo - UNIFESP - São Paulo (SP), Brazil; Clínica Oftalmológica Renato Ambrósio - Rio de Janeiro (RJ), Brazil.

Physician, Ophthalmology Department, Escola Paulista de Medicina, Universidade Federal de São Paulo - UNIFESP - São Paulo (SP), Brazil.

Physician, Sociedade Brasileira de Administração em Oftalmologia - SBAO - Rio de Janeiro (RJ), Brazil.

Physician, Clínica Oftalmológica Renato Ambrósio - Rio de Janeiro (RJ), Brazil.

Statistician, Statistics Department, Universidade Federal Fluminense - UFF - Rio de Janeiro (RJ), Brazil.

${ }^{5}$ Physician, Universidade Metropolitana de Santos - UNIMES - Santos (SP), Brazil.

Correspondence address: Bruno M. Fontes. Rua Castro Alves, 10 - Rio de Janeiro (RJ) CEP 20775-040 - E-mail: brunomfontes@terra.com.br

Recebido para publicação em 30.07.2010

Última versão recebida em 07.05.2010

Aprovação em 12.07.2010

No financial support was available for this project.

Renato Ambrosio, MD is a consultant for Oculus and Reichert Companies.

Nota Editorial: Depois de concluída a análise do artigo sob sigilo editorial e com a anuência dos Drs. Luis Alberto Carvalho e Diane Ruschel Marinho sobre a divulgação de seus nomes como revisores, agradecemos sua participação neste processo.

\section{INTRODUCTION}

K eratoconus is an ectatic disease of the cornea, with progressive noninflammatory thinning and anterior protrusion that leads to an irregular conical shape ${ }^{(1-4)}$. It is usually a bilateral and asymmetric condition that manifests at puberty. Clinical (as corneal stromal thinning, conical protrusion, Vogt striae and Fleischer ring) and topographic (as irregular astigmatism, inferior steepening and inferior-superior asymmetry) findings are habitually combined for diagnosing and staging the disease ${ }^{(5-6)}$.

Recently, new technology in eye imaging such as the Pentacam (Oculus Inc, Wetzlar, Germany) has revealed valuable information regarding corneal and anterior segment anatomy. These developments can be credited, primarily, to progress in refractive surgery and the need for better preoperative screening. Diagnosis of keratoconus has been improved by curvature (elevation) maps, corneal pachymetric distribution, corneal volume and anterior segment data, which have all been 
provided by a variety of currently available equipment ${ }^{(5-14)}$. However, accurate differentiation of keratoconus from healthy corneas is not yet sufficient, as there is a need to detect corneas with a higher susceptibility to becoming ectatic after laser photoablative surgery ${ }^{(15-16)}$

In vivo corneal biomechanical evaluation was first described by Luce ${ }^{(17)}$ in 2005, with the development of the Ocular Response Analyzer (ORA, Reichert Ophthalmic Instruments, Depew, New York, USA). A number of researchers published diverse and exciting new data regarding corneal hysteresis $(\mathrm{CH})$ and corneal resistance factor (CRF) in healthy and pathological conditions ${ }^{(18-22)}$. If ORA proves that "fragile" corneas are more susceptible than "strong" corneas to developing ectasia in the future, then the best use for such data in refractive surgery would be in preoperative screening.

The present study compared the findings of biomechanical and anterior segment parameters in differentiating keratoconus from healthy corneas, and evaluated the ability of each individual parameter to differentiate them.

\section{METHODS}

This was a comparative case series. The research followed the tenets of the Declaration of Helsinki and was approved by the ethics committee of the Federal University of São Paulo (protocol 0123/06). All subjects were informed about the purpose of the study and gave informed consent before inclusion. Patients were sequentially evaluated from October 2005 to December 2008. Demographic and clinical data were obtained, including date of birth, gender and self-reported race or ethnicity.

The keratoconus group consisted of 77 eyes from 43 patients ( 24 male, 19 female) with a mean age of $34.95 \pm 11.95$ years (ranging from 18 to 73 years). The control group consisted of 86 eyes from 43 ( 24 male, 19 female) gender- and agematched healthy patients, with a mean age of $35.02 \pm 12.19$ years (ranging from 18 to 72 years-old) $(p=1)$.

Each subject underwent a comprehensive ophthalmologic examination including review of medical history, bestcorrected visual acuity, slit lamp biomicroscopy, fundoscopic examination, Placido disc topography (Humphrey ATLAS, Carl Zeiss Meditec Inc. Dublin, USA), Pentacam tomographic evaluation and ORA measurements.

Diagnosis of keratoconus was made by clinical (corneal stromal thinning, Vogt's striae, Fleischer ring, scissoring of the red reflex or oil droplet sign identified by retinoscopy) and topographic (an increased area of corneal power surrounded by concentric areas of decreasing power, inferior-superior power asymmetry, and skewing of the steepest radial axes above and below the horizontal meridian ${ }^{(2,5-6,10,23)}$ evaluation.

Cases were gender- and age-matched with controls for data comparison ${ }^{21}$. Exclusion criteria were: less than 18 yearsold, any previous corneal or ocular surgery, any eye disease that could possibly interfere with the readings/results (e.g., glaucoma, uveitis, corneal ectatic disease, Fuch's dystrophy, diabetic retinopathy, etc.) chronic and/or continuous use of topical medications, corneal scars and/or opacities, irregular astigmatism, systemic collagen diseases and refusal to sign an informed consent agreement. Contact lenses were required to be removed at least $72 \mathrm{~h}$ before examination.

Patients underwent testing with the ORA and Pentacam during the same visit. All measurements were taken between 8:00 AM and 6:00 PM. Two consecutive ORA measurements were performed on both eyes and the results were averaged. Only high-quality readings (defined by the manufacturer as both the force-in and force-out applanation signal peaks on the ORA waveform being fairly symmetrical in height) were stored. The Pentacam assessed central keratometry (K-Ave), corneal astigmatism (CA), central corneal thickness (CCT), anterior chamber depth (AC depth) and corneal volume (CV).

The Pentacam system was connected to a personal computer, with automated software. The manufacturer performed calibration of the device. The system uses a rotating Scheimpflug camera and a monochromatic slit light source (a blue lightemitting diode at $475 \mathrm{~nm}$ ) that rotate together. After proper alignment of the patient's face, a fixation target is shown, which guides the patient's gaze. A real-time image of the patient's eye is shown to the examiner on the computer screen, and the image is manually focused and centered. The rotating camera is set to take 25 slit images of the anterior eye segment in approximately 2 seconds with 500 true elevation points incorporated in each slit image. Minute eye movements are captured by a second camera and corrected simultaneously. Single point pachymetric measurements of the entire cornea are calculated from the anterior and posterior corneal surfaces.

The ORA determines corneal biomechanical properties using an applied force-displacement relationship. Details have been extensively described in previous studies ${ }^{17}$. Briefly, a precisely-metered air pulse is delivered to the eye, causing the cornea to move inward, past a first applanation, and into a slight concavity. Milliseconds after the first applanation, the air pump is shut down and the pressure applied to the eye decreases in an inverse-time, symmetrical fashion. As the pressure decreases, the cornea passes through a second applanated state while returning from concavity to its normal convex curvature. Energy absorption during rapid corneal deformation delays the occurrence of the inward and outward applanation signal peaks, resulting in a difference between the applanation pressures. The difference between these inward and outward motion applanation pressures is called corneal hysteresis $(\mathrm{CH})$. Corneal hysteresis is an indication of viscous damping and elastic resistance, reflecting the capacity of corneal tissue to absorb and dissipate energy. Corneal resistance factor (CRF) was empirically derived to maximize correlation to CCT, and it can be considered to be weighted by elastic resistance since it has a stronger correlation to $\mathrm{CCT}$ than $\mathrm{CH}$. Though $\mathrm{CH}$ and $\mathrm{CRF}$ are related, in some instances they can be significantly different, each providing distinct information about the cornea.

The Kolmogorov-Smirnov test was used to check for a normal distribution of quantitative data, which are provided as the mean and standard deviation (SD). Differences between data were evaluated using the Welch modified Student's twosample $t$-test and Wilcoxon rank-sum test. The level of significance for each parameter was set at $p<0.05$. A receiver operating characteristic (ROC) curve was used to identify the cutoff point of studied parameters to maximize sensitivity and specificity in discriminating keratoconus from normal corneas. This curve is obtained by plotting sensitivity against 1- specificity, calculated for each value observed. An ideal area of 100\% implies that the test perfectly discriminates between groups. Logistic regression was used to support the cutoff point identified with the ROC curve analysis.

\section{RESULTS}

K-Ave was $47.03 \pm 5.22$ diopters (D) (range 40.4 to 74.15 D) in keratoconus and $43.31 \pm 1.53 \mathrm{D}$ (range 39.9 to $46.75 \mathrm{D}$ ) in the control group $(p=0)$. CA was $3.46 \pm 2.20 \mathrm{D}$ (range 0.7 to $10.9 \mathrm{D}$ ) in keratoconus and $1.08 \pm 0.81 \mathrm{D}$ (range 0 to $4.9 \mathrm{D}$ ) in the control group $(p=0)$. CCT was $493.17 \pm 42.84 \mu \mathrm{m}$ (range 349 to $568 \mu \mathrm{m}$ ) in keratoconus and $543.90 \pm 34.87 \mu \mathrm{m}$ (range from 457 to $627 \mu \mathrm{m})$ in the control group $(p=0)$ (Figure 1). AC depth was $3.25 \pm 0.38 \mathrm{~mm}$ (range 2.41 to $5.21 \mathrm{~mm}$ ) in keratoconus and $3.07 \pm 0.42 \mathrm{~mm}$ (range 2.08 to $3.80 \mathrm{~mm}$ ) in the 
control group ( $p=0.012$ ). CV was $57.01 \pm 3.53 \mathrm{~mm}^{3}$ (range 49.5 to $66.9 \mathrm{~mm}^{3}$ ) in keratoconus and $60.19 \pm 3.40 \mathrm{~mm}^{3}$ (range 53.7 to $\left.68.5 \mathrm{~mm}^{3}\right)$ in the control group $(p=0)$.

$\mathrm{CH}$ was $8.23 \pm 1.51 \mathrm{mmHg}$ (range 4.60 to $11.80 \mathrm{mmHg}$ ) in keratoconus and $10.13 \pm 1.75 \mathrm{mmHg}$ (range 5.95 to $14.58 \mathrm{mmHg}$ ) in the control group $(p=0)$ (Figure 2). CRF was $7.46 \pm 1.76$ $\mathrm{mmHg}$ (range 2.80 to $11.20 \mathrm{mmHg}$ ) in keratoconus and $10.06 \pm$ $1.97 \mathrm{mmHg}$ (range 5.45 to $15.10 \mathrm{mmHg}$ ) in the control group $(p=0)$ (Figure 3). The results are summarized in table 1.

ROC curve analyses showed poor overall predictive accuracy for all studied parameters in differentiating keratoconus from normal corneas. The results are summarized in table 2.

Higher sensitivity in differentiating keratoconus from healthy corneas was $79.2 \%$ for $\mathrm{AC}$ depth and $\mathrm{CH}$ (cutoff point $3.22 \mathrm{~mm}$ and $9.39 \mathrm{mmHg}$ respectively); the best specificity and test accuracy for CA (cutoff point 2.2 D; $89.5 \%$ and $80.34 \%$ respectively). Lowest sensitivity was $62 \%$ for $C V$, with a specificity of 44.2\% for AC depth and $69.93 \%$ test accuracy for K-Ave.

The cutoff point for K-Ave was $44.35 \mathrm{D}$ with sensitivity of $74 \%$, specificity of $66.3 \%$ and test accuracy of $69.93 \%$. For CA the cutoff point was $2.2 \mathrm{D}$ with sensitivity of $70.1 \%$, specificity of $89.5 \%$ and test accuracy of $80.34 \%$. The cutoff point for CCT was $521 \mu \mathrm{m}$, with sensitivity of $77.9 \%$, specificity of $80.2 \%$ and test accuracy of $79.11 \%$. The cutoff point for AC depth was $3.22 \mathrm{~mm}$, with sensitivity of $79.2 \%$, specificity of $44.2 \%$ and test accuracy of $60.72 \%$. The cutoff point for CV was $57.8 \mathrm{~mm}^{3}$, with sensitivity of $62 \%$, specificity of $77.9 \%$ and test accuracy of $70.71 \%$. The cutoff point was $9.39 \mathrm{mmHg}$ for $\mathrm{CH}$, with sensitivity of $79.2 \%$, specificity of $70.9 \%$ and test accuracy of $74.82 \%$ (ROC curve for $\mathrm{CH}$ is seen in Figure 4). The cutoff point was $8.68 \mathrm{mmHg}$ for CRF, with sensitivity of $77.9 \%$, specificity of $75.6 \%$ and test accuracy of $76.69 \%$.

\section{DISCUSSION}

Biomechanical study of the cornea is crucial for refractive surgery progress not only for better preoperative screening, but also for prediction of individual outcomes. As Ethier et al. ${ }^{(24)}$ stated, material properties of the cornea are heterogeneous, highly anisotropic, nonlinear, and viscoelastic. In a broad review, Torres et al. ${ }^{(25)}$ described CCT and corneal collagen fiber density as the most important intrinsic factors determining corneal biomechanics. We would include corneal hydration (and its control by the endothelium), corneal thickness regional variation, collagen fibril orientation and distribution.

Kida et al. ${ }^{(26)}$, and Laiquzzaman et al. ${ }^{(27)}$ found that $\mathrm{CH}$ remained almost constant throughout the day, whereas CCT and intraocular pressure showed statistically significant variations (higher values during the nocturnal period) in young adults. The small number of patients in both studies might restrict their findings to these specific populations. Previous studies, including ours ${ }^{(21)}$, indicate a through relation between $\mathrm{CRF}$ and $\mathrm{CH}$ with CCT and an inverse relation with age. The present data, in agreement with previous research ${ }^{(28-30)}$, show that biomechanical metrics are statistically lower in keratoconus then in normal corneas. However, the big overlap of the results of both groups involves the issue of accuracy in discriminating normal from abnormal corneas. New data presented recently by David Luce (ASCRS 2009 meeting, San Francisco - CA) regarding waveform parameters provided from the ORA signal may turn out to be more sensitive than $\mathrm{CH}$ and $\mathrm{CRF}$ in discriminating abnormal corneas.

Anterior segment tomography has been the subject of

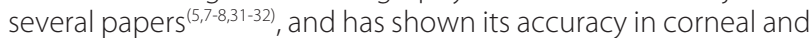
anterior segment mapping. New parameters, such as corneal volume, pachymetric progression and elevation maps are of $\mu \mathrm{m}$

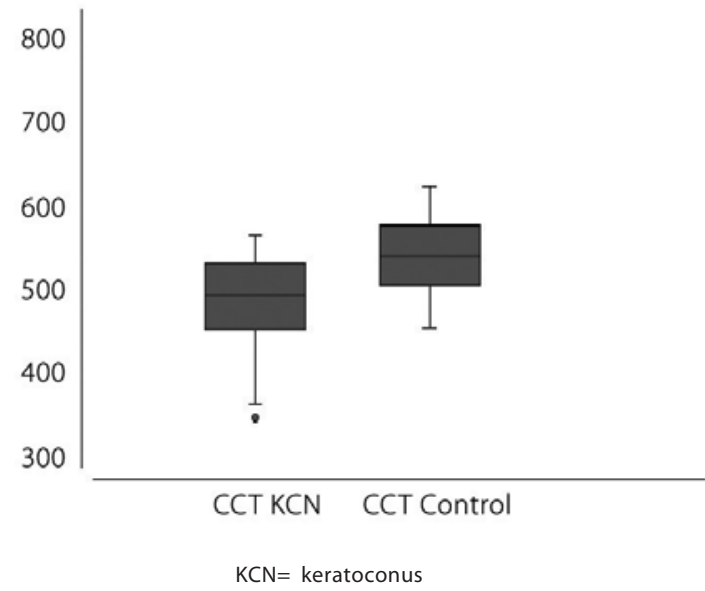

Figure 1. Central corneal thickness (CCT) distribution.

$\mathrm{mmHg}$

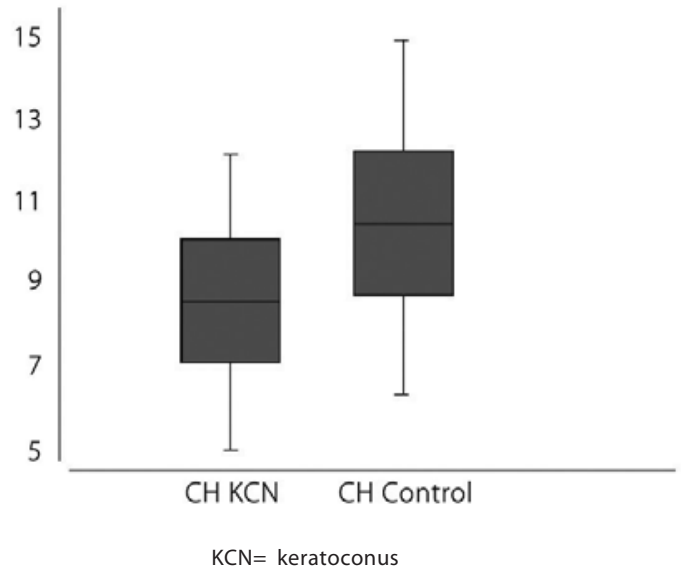

Figure 2. Corneal hysteresis $(\mathrm{CH})$ distribution.

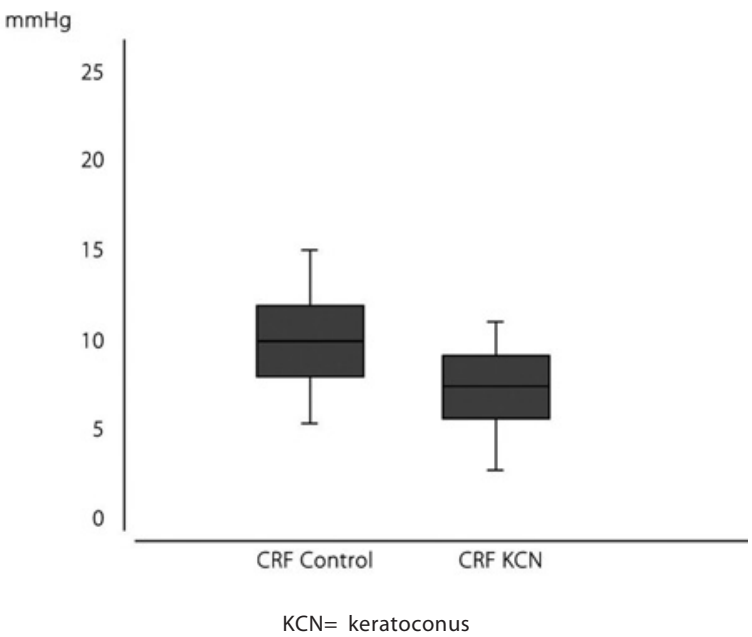

Figure 3. Corneal resistance factor (CRF) distribution. 
Table 1. Summary of the anterior segment parameters and biomechanical metrics results of studied population

\begin{tabular}{|c|c|c|c|c|c|c|c|}
\hline & K-Ave (D) & CA (D) & CCT $(\mu \mathrm{m})$ & AC depth (mm) & $\mathrm{CV}\left(\mathrm{mm}^{3}\right)$ & $\mathrm{CH}(\mathrm{mmHg})$ & CRF $(\mathrm{mmHg})$ \\
\hline $\begin{array}{l}\text { Keratoconus } \\
(\text { mean } \pm S D) \\
(\min -\max )\end{array}$ & $\begin{array}{c}47.03 \pm 5.22 \\
40.40-74.15\end{array}$ & $\begin{array}{l}3.46 \pm 2.20 \\
0.70-10.90\end{array}$ & $\begin{array}{l}493.17 \pm 42.84 \\
349.00-568.00\end{array}$ & $\begin{array}{l}3.25 \pm 0.38 \\
2.41-5.21\end{array}$ & $\begin{array}{l}57.01 \pm 3.53 \\
49.50-66.90\end{array}$ & $\begin{array}{l}8.23 \pm 1.51 \\
4.60-11.80\end{array}$ & $\begin{array}{l}7.46 \pm 1.76 \\
2.80-11.20\end{array}$ \\
\hline $\begin{array}{l}\text { Controls } \\
(\text { mean } \pm S D) \\
(\min -\max )\end{array}$ & $\begin{array}{l}43.31 \pm 1.53 \\
39.90-46.75\end{array}$ & $\begin{array}{r}1.08 \pm 0.81 \\
0-4.90\end{array}$ & $\begin{array}{l}543.90 \pm 34.87 \\
457.00-627.00\end{array}$ & $\begin{array}{c}3.07 \pm 0.42 \\
2.08-3.80\end{array}$ & $\begin{array}{c}60.19 \pm 3.40 \\
53.70-68.50\end{array}$ & $\begin{array}{r}10.13 \pm 1.75 \\
5.95-14.58\end{array}$ & $\begin{array}{r}10.06 \pm 1.97 \\
5.45-15.10\end{array}$ \\
\hline
\end{tabular}

$\mathrm{SD}=$ standard deviation; $\mathrm{min}=$ minimum; $\mathrm{max}=$ maximum; $\mathrm{D}=$ diopters; $\mu \mathrm{m}=$ micrometers; $\mathrm{mm}=$ millimeters; $\mathrm{mmHg}=$ millimeters of $\mathrm{mercury} ; \mathrm{K}-\mathrm{Ave}=\mathrm{cen}$ tral $\mathrm{keratometry} ;$ $\mathrm{CA}=$ corneal astigmatism; $\mathrm{CCT}=$ central corneal thickness; $\mathrm{AC}$ depth=anterior chamber depth; $\mathrm{CV}=$ corneal volume; $\mathrm{CH}=\mathrm{Corneal}$ hysteresis; $\mathrm{CRF}=\mathrm{corneal}$ resistance factor

Table 2. Receiver operating characteristic (ROC) identified the best cutoff point of studied parameters to maximize sensitivity and specificity in differentiating keratoconus and healthy corneas

\begin{tabular}{lcccc}
\hline & $\begin{array}{c}\text { Cutoff } \\
\text { point }\end{array}$ & $\begin{array}{c}\text { Sensitivity } \\
\text { (\%) }\end{array}$ & $\begin{array}{c}\text { Specificity } \\
\text { (\%) }\end{array}$ & $\begin{array}{c}\text { Test } \\
\text { accuracy }\end{array}$ \\
\hline K-Ave & $44.35 \mathrm{D}$ & 74.0 & 66.3 & 69.93 \\
CA & $2.2 \mathrm{D}$ & 70.1 & 89.5 & 80.34 \\
CCT & $521 \mu \mathrm{m}$ & 77.9 & 80.2 & 79.11 \\
AC depth & $3.22 \mathrm{~mm}$ & 79.2 & 44.2 & 60.72 \\
CV & $57.8 \mathrm{~mm}^{3}$ & 62.0 & 77.9 & 70.71 \\
CH & $9.39 \mathrm{mmHg}^{2}$ & 79.2 & 70.9 & 74.82 \\
CRF & $8.68 \mathrm{mmHg}^{\prime}$ & 77.9 & 75.6 & 76.69 \\
\hline
\end{tabular}

$\mathrm{K}$-Ave $=$ central keratometry; $\mathrm{CA}=$ corneal astigmatism; $C C T=$ central corneal thickness; $\mathrm{AC}$ depth= anterior chamber depth; $\mathrm{CV}=$ corneal volume; $\mathrm{CH}=$ corneal hysteresis; CRF= corneal resistancefactor

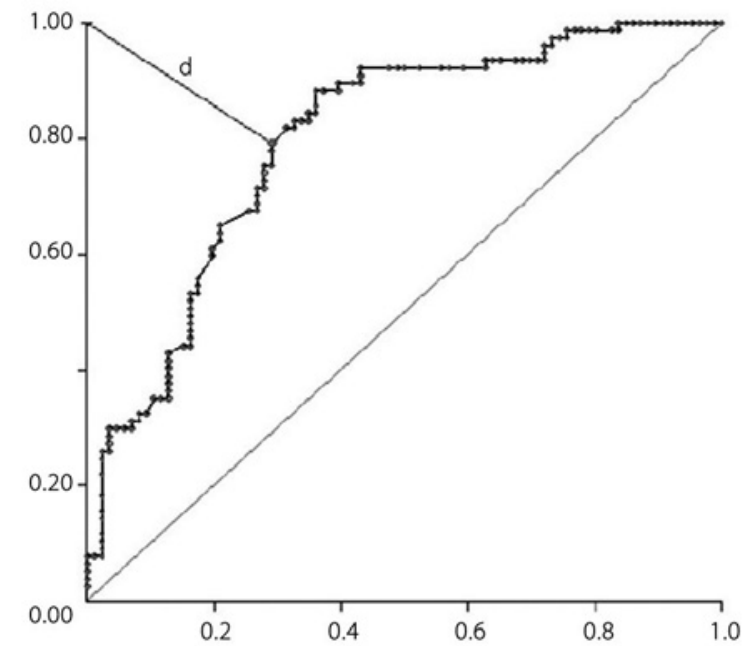

$d=$ distance from cutoff point to the upper left corner or coordinate $(0,1)$ of the ROC space (the best possible prediction point that represents $100 \%$ of sensitivity and specificity, also called a perfect classification).

Figure 4. Receiver operating characteristic (ROC) curve (graphical plot of the sensitivity vs. 1 - specificity) for corneal hysteresis $(\mathrm{CH})$ data. Cutoff point was $9.39 \mathrm{mmHg}$, with sensitivity of $79.2 \%$, specificity of $70.9 \%$ and test accuracy of $74.82 \%$. great utility in clinical practice ${ }^{(8-10,13-14,33-36)}$. In the present study, we were able to detect statistical difference in all anterior segment parameters given by the Pentacam rotating Scheimpflug camera. But, as in CH and CRF, a big overlap was found. The corneal color maps given by the Pentacam, as well as automated software for keratoconus screening and new indices such as the Belin/Ambrosio enhanced ectasia screening did not constitute a subject of our study. We studied only the isolated data given by the machine during anterior segment screening.

In conclusion, although all studied parameters showed statistical differences between the two groups, when considered individually they showed low sensitivity, specificity and test accuracy for keratoconus and healthy cornea differentiation. Corneal maps and automated software given by the Pentacam were not the subject of our study. New studies are warranted to expand the knowledge of corneal biomechanical metrics and anterior segment tomography.

\section{REFERENCES}

1. Shirayama-Suzuki M, Amano S, Honda N, Usui T, Yamagami S, Oshika T. Longitudinal analysis of corneal topography in suspected keratoconus. Br J Ophthalmol. 2009;93(6):815-9. Comment in: Br J Ophthalmol. 2009;93(7):845-7.

2. Reeves SW, Ellwein LB, Kim T, Constantine R, Lee PP. Keratoconus in the Medicare population. Cornea. 2009:28(1):40-2

3. Ertan A, Muftuoglu O. Keratoconus clinical findings according to different age and gender groups. Cornea. 2008;27(10):1 109-13. Comment in: Cornea. 2009;28(7):836 author reply 836

4. Rabinowitz YS. Keratoconus. Surv Ophthalmol. 1998;42(4):297-319. Review.

5. Vinciguerra P, Albè E, Trazza S, Rosetta P, Vinciguerra R, Seiler T, Epstein D. Refractive, topographic, tomographic, and aberrometric analysis of keratoconic eyes undergoing corneal cross-linking. Ophthalmology. 2009;116(3):369-78. Comment in: Ophthalmology. 2009:116(10):2036-7; author reply 2037-8.

6. Wang $M$, editor. Corneal topography in the wavefront era: a guide for clinical application. Thorofare, NJ: Slack Inc.; 2006. p. xvi, 313.

7. Prospero Ponce CM, Rocha KM, Smith SD, Krueger RR. Central and peripheral corneal thickness measured with optical coherence tomography, Scheimpflug imaging, and ultrasound pachymetry in normal, keratoconus-suspect, and postlaser in situ keratomileusis eyes. J Cataract Refract Surg. 2009;35(6):1055-62.

8. Piñero DP, Alió لاL, Alesón A, Escaf M, Miranda M. Pentacam posterior and anterior corneal aberrations in normal and keratoconic eyes. Clin Exp Optom. 2009; 92(3):297-303.

9. Miranda MA, Radhakrishnan H, O'Donnell C. Repeatability of corneal thickness measured using an Oculus Pentacam. Optom Vis Sci. 2009;86(3):266-72.

10. EmreS, Doganay S, Yologlu S. Evaluation of anterior segment parameters in keratoconic eyes measured with the Pentacam system. J Cataract Refract Surg. 2007;33(10):1708-12.

11. de Sanctis U, Missolungi A, Mutani B, Richiardi L, Grignolo FM. Reproducibility and repeatability of central corneal thickness measurement in keratoconus using the rotating Scheimpflug camera and ultrasound pachymetry. Am J Ophthalmol. 2007; 144(5):712-8.

12. Uçakhan OO, Ozkan M, Kanpolat A. Corneal thickness measurements in normal and keratoconic eyes: Pentacam comprehensive eye scanner versus noncontact specular microscopy and ultrasound pachymetry. J Cataract Refract Surg. 2006;32(6):970-7. 
13. Luz A, Ursulio M, Castaneda D, Ambrosio R Jr. Progressão da espessura corneana do ponto mais fino em direção ao limbo: estudo de uma população normal e de portadores de ceratocone para criação de valores de referência. Arq Bras Oftalmol. 2006;69(4):579-83

14. Ambrosio R Jr, Alonso RS, Luz A, Coca Velarde LG. Corneal-thickness spatial profile and corneal-volume distribution: tomographic indices to detect keratoconus. $J$ Cataract Refract Surg. 2006;32(11):1851-9.

15. Randleman JB. Post-laser in-situ keratomileusis ectasia: current understanding and future directions. Curr Opin Ophthalmol. 2006:17(4):406-12.

16. Rabinowitz YS. Ectasia after laser in situ keratomileusis. Curr Opin Ophthalmol. 2006;17(5):421-6.

17. Luce DA. Determining in vivo biomechanical properties of the cornea with an ocular response analyzer. J Cataract Refract Surg. 2005;31(1):156-62.

18. Sun L, Shen M, Wang J, Fang A, Xu A, Fang H, Lu F. Recovery of corneal hysteresis after reduction of intraocular pressure in chronic primary angle-closure glaucoma. Am J Ophthalmol. 2009;147(6):1061-6, 1066 e1-2.

19. Shen M, Wang J, Qu J, Xu S, Wang X, Fang H, Lu F. Diurnal variation of ocula hysteresis, corneal thickness, and intraocular pressure. Optom Vis Sci. 2008;85(12): 1185-92.

20. Shah S, Laiquzzaman M, Mantry S, Cunliffe I. Ocular response analyser to assess hysteresis and corneal resistance factor in low tension, open angle glaucoma and ocular hypertension. Clin Experiment Ophthalmol. 2008;36(6):508-13. Comment in: Clin Experiment Ophthalmol. 2008;36(6):499-500.

21. Fontes BM, Ambrosio R Jr, Alonso RS, Jardim D, Velarde GC, Nosé W. Corneal biomechanical metrics in eyes with refraction of -19.00 to $+9.00 \mathrm{D}$ in healthy Brazilian patients. J Refract Surg. 2008;24(9):941-5.

22. Kotecha A. What biomechanical properties of the cornea are relevant for the clinician? Surv Ophthalmol. 2007:52 Suppl 2:S109-14

23. McMahon TT, Szczotka-Flynn L, Barr JT, Anderson RJ, Slaughter ME, Lass JH, lyengar SK; CLEK Study Group. A new method for grading the severity of keratoconus: the Keratoconus Severity Score (KSS). Cornea. 2006;25(7):794-800.

24. Ethier CR, Johnson M, Ruberti J. Ocular biomechanics and biotransport. Annu Rev Biomed Eng. 2004;6:249-73
25. Torres RM, Merayo-Lloves J, Jaramillo MA, Galvis V. [Corneal biomechanics]. Arch Soc Esp Oftalmol. 2005;80(4):215-23. Spanish.

26. Kida T. Liu JH, Weinreb RN. Effects of aging on corneal biomechanical properties and their impact on 24-hour measurement of intraocular pressure. Am J Ophthalmol. 2008;146(4):567-72.

27. Laiquzzaman M, Bhojwani R, Cunliffe I, Shah S. Diurnal variation of ocular hysteresis in normal subjects: relevance in clinical context. Clin Experiment Ophthalmol. 2006;34(2):114-8. Comment in: Clin Experiment Ophthalmol. 2006; 34(2):100-1.

28. Saad A, Lteif Y, Azan E, Gatinel D. Biomechanical properties of keratoconus suspect eyes. Invest Ophthalmol Vis Sci. 2010;51(6):2912-6.

29. Fontes BM, Ambrosio R Jr, Velarde GC, Nosé W. Ocular Response Analyzer Measurements in Keratoconus with Normal Central Corneal Thickness Compared with Matched Normal Control Eyes. J Refract Surg. 2010 May 19:1-7.

30. Fontes BM, Ambrosio R Jr, Jardim D, Velarde GC, Nosé W. Corneal biomechanical metrics and anterior segment parameters in mild keratoconus. Ophthalmology. 2010;117(4):673-9

31. Swartz T, Marten L, Wang M. Measuring the cornea: the latest developments in corneal topography. Curr Opin Ophthalmol. 2007;18(4):325-33.

32. Konstantopoulos A, Hossain P, Anderson DF. Recent advances in ophthalmic anterior segment imaging: a new era for ophthalmic diagnosis? Br J Ophthalmol. 2007; 91(4):551-7.

33. Lema I, Romero P, Mato JL, Feijóo ED. Corneal descriptive indices in the fellow eye of unilateral keratoconus. Eye Contact Lens. 2009:35(2):65-8.

34. Kawamorita T, Uozato H, Kamiya K, Bax L, Tsutsui K, Aizawa D, Shimizu K. Repeatability, reproducibility, and agreement characteristics of rotating Scheimpflug photography and scanning-slit corneal topography for corneal power measurement. J Cataract Refract Surg. 2009;35(1):127-33

35. Belin MW, Khachikian SS. An introduction to understanding elevation-based topography: how elevation data are displayed - a review. Clin Experiment Ophthalmol. 2009;37(1):14-29.

36. Li Y, Meisler DM, Tang M, Lu AT, Thakrar V, Reiser BJ, Huang D. Keratoconus diagnosis with optical coherence tomography pachymetry mapping. Ophthalmology. 2008 115(12):2159-66

\section{Envie seu trabalho pelo site dos ABO}<smiles>[CH]1CC1</smiles>
www.aboonline.com.br 